\title{
Pemanfaatan Abu Ampas Tebu Limbah Pabrik Gula Cinta Manis Kabupaten Ogan Ilir Sebagai Additive Beton
}

\author{
Adiguna $^{1 *}$, Agus Wahyudi ${ }^{2}$ \\ *e-mail: adigunaym@gmail.com \\ ${ }^{1}$ Program Studi Teknik Sipil, Fakultas Teknik Universitas PGRI Palembang \\ ${ }^{2}$ Program Studi Teknik Kimia, Fakultas Teknik Universitas PGRI Palembang
}

\begin{abstract}
Cane is one of the plantation commodities managed as raw material for making sugar. PT. Cinta Manis as one of the sugar producers has sugarcane production and management activities on a large scale. Production of sugar with raw material in large quantities every day, produces a by-product of sugarcane bagasse waste. Currently sugarcane bagasse waste is only used as compost after going through several stages of processing. The study was conducted in a laboratory by physically changing cane bagasse to ash through burning. Furthermore, the ash from the sugarcane bagasse was added to high quality concrete $\mathrm{K}-300$. The results of the laboratory tests carried out showed that the addition of Cane Bagasse Ash (CBA) by 5\% can increase the compressive strength of the concrete $6.43 \%$ higher than the normal compressive strength of the concrete. However, the addition of CBA which is greater than 5\% to the cement in the concrete actually decreases the quality of the compressive strength of the concrete. This means that the 5\% CBA content can be used to increase the compressive strength of concrete.
\end{abstract}

Keywords: ash, cane bagasse, concrete additive

\begin{abstract}
ABSTRAK
Tebu merupakan salah satu komoditas perkebunan yang dikelola sebagai bahan baku pembuatan gula. PT. Cinta Manis sebagai salah satu produsen gula, memiliki aktivitas produksi dan pengelolaan tebu dalam skala besar. Produksi gula dengan bahan baku tebu dalam jumlah yang besar setiap hari, menghasilkan produk sampingan berupa limbah ampas tebu. Saat ini limbah ampas tebu hanya dimanfaatkan sebagai pupuk kompos setelah melalui beberapa tahapan pengolahan. Penelitian dilakukan di laboratorium dengan mengubah fisik ampas tebu menjadi abu melalui pembakaran Selanjutnya abu dari ampas tebu tersebut ditambahkan ke beton mutu tinggi K-300. Hasil dari uji labor yang dilaksanakan didapatkan hasil bahwa penambahan Abu Ampas Tebu (AAT) sebanyak $5 \%$ dapat menambah kuat tekan beton tersebut 6,43\% lebih tinggi dari kuat tekan beton normalnya. Namun penambahan AAT yang lebih besar dari $5 \%$ terhadap semen dalam beton tersebut justru menurunkan kualitas kuat tekan betonnya. Hal ini berarti jumlah kadar $5 \%$ AAT dapat dimanfaatkan untuk peningkatan kuat tekan beton.
\end{abstract}

Kata Kunci: abu, ampas tebu, additive beton

\section{PENDAHULUAN}

Propinsi Sumatera Selatan sebagai provinsi yang kaya akan hasil perkebunan mempunyai keberagaman pemanfaatan hasil perkebunan. Diantara hasil kebun yang dikelola serta dimanfaatkan di daerah ini merupakan hasil dari 
perkebunan tebu yang dimanfaatkan selaku bahan baku pembuatan gula. Salah satu kabupaten di Propinsi Sumatera Selatan tepatnya di Kabupaten Ogan Ilir terdapat industri perkebunan yakni PTPN. Cinta Manis yang mengelola perkebunan tebu serta mengolahnya jadi gula.

Salah satu permasalah yang mencuat dari aktivitas pembuatan gula tersebut merupakan limbah perasan air tebu berbentuk ampas tebu. Limbah ampas tebu yang dihasilkan dari aktivitas tersebut jumlahnya melimpah serta belum dimanfaatkan secara maksimal serta bila tidak diolah dengan baik malah bisa jadi limbah berbentuk sampah padat yang bisa mencemari suatu kawasan.

Limbah ampas tebu pabrik gula yang selama ini dibuang begitu saja ke lingkungan serta jadi sumber pencemaran kawasan yang bisa diolah jadi material bangunan yang berguna. Data- data hasil uji labor dengan menyamakan sebagian modifikasi konsentrasi abu ampas tebu bisa memberikan cerminan seberapa besar pengaruhnya terhadap kenaikan mutu kualitas beton.

Beton ialah kombinasi antara semen Portland ataupun semen hidraulik dengan komponen yang lain berbentuk agregat yang berukutan halus, agregat yang berdimensi lebih bear ataupun kasar serta air, dengan ataupun tanpa bahan kombinasi tambahan membentuk masa padat (SK SNI, 1990).

Walaupun di dalam Standar Nasional Indonesia (SNI) sudah diatur khusus mengenai desain beton bersumber pada kualitas kekokohannya. Tetapi standar properti bahan yang digunakan selaku standar riset wajib senantiasa dilakukan uji coba awal bahan serta uji coba sempel beton. Tujuannya supaya diketahuai apakah standar yang digunakan memberikan hasil kualitas cocok dengan apa yang direncanakan apabila memakai bahan baku lokal. Berikutnya dicoba penyesuaian volume maupaun konsentrasi bahan yang digunakan serta dilakukan ujicoba secara kesekian hingga didapatkan komposisi bahan yang menciptakan kualitas yang cocok dengan yang direncanakan.

Beton merupakan peranan dari bahan penyusunnya yang terdiri dari bahan semen hidrolik (Portland cemen), agregat kasar, agregat halus, air serta bahan tambah (Mulyono, 2003).

Semen selaku bahan pengikat sendiri mempunyai komposisi serta hasil kualitas yang berbeda- beda antara merk serta tipe yang terdapat di lokasi riset. Hal ini disebabkan komposisi bahan serta asalnya yang berbeda- beda. Pada riset ini didetetapkan satu tipe merk semen yang digunakan. Agregat yang digunakan baik halus ataupun kasar diambil dari sumber yang sama buat seluruh sempel riset yang terbuat.

Bahan- bahan semacam agregat halus, agregat kasar, air, serta semen dicampur sampai homogen dengan perbandingan tertentu sehingga menciptakan sesuatu kondisi yang sifatnya plastis yang tujuannya buat memudahkan pengerjaannya, serta apabila dibutuhkan hingga bisa ditambahkan bahan tambah (admixture). Panas hidrasi yang terjalin akibat semen serta air lewat respon kimia bakal membentuk sesuatu jalinan antara butiran agregat( halus serta kasar), dengan air serta semen tersebut, sehingga menciptakan pengerasan serta akumulasi kekuatan, dimana beton bakal mengalami akumulasi kekuatan secara terus menerus sampai menggapai kekuatan maksimum pada usia beton lebih dari 28 hari.

Bersumber pada latar belakang yang sudah dijabarkan di atas hingga yang jadi fokus dalam rumusan permasalahan yakni bagaimana membuat desain beton yang diberikan bahan tambah additive dengan konsentrasi tertentu sanggup tingkatkan mutu beton Kualitas Tinggi. 
Tujuan riset ini merupakan meyakinkan kalau ampas tebu yang diolah jadi abu bisa dijadikan bahan additive buat tingkatkan kualitas beton $\mathrm{K}$ 300.

Mengingat beton dibuat dari komposisi bahan yang bermacammacam hingga kualitas beton bakal terpengaruh oleh sifat masing- masingmasing bahannya yang dipengaruhi juga metode pengerjaannya, serta area dimana beton itu terbuat serta digunakan. Beton bagaikan bahan konstruksi bangunan dalam pemanfaatannya hendaklah mencermati tujuan yang hendak dicapai. Oleh karena itu komposisi kombinasi bahan baku bergantung pada tujuan pemakaian serta kekuatan dari beton. Berlandaskan hal ini, hingga diketahui pengelompokan tipe beton yang difokuskan pada berat volume, kelas serta kualitas beton. Kekuatan dan bersumber pada metode serta pembuatannya.

Tipe beton yang dikususkan pada beratnya terdiri dari beton berat, beton normal, beton ringan serta beton setengah berat.(Sumardi, 1998).

Berdasarkan pada pengelompokan tersebut, berat beton yang direncanakan pada sesuatu bangunan konstuksi bakal sangat mempengaruhi pada desain strukturnya paling utama buat berat sendiri bangunan tersebut.

Kuat tekan beton membuktikan kualitas dari sesuatu struktur dimana semakin tinggi kekuatan struktur yang diinginkan, hingga terus menjadi tinggi pula kualitas beton yang dihasilkan. kekuatan tekan beton dinotasikan seperti (Wangsadinata, 1989):

Fc' :Kekuatan tekan beton yang diisyaratkan

Fck :Kekuatan tekan beton yang didapatkan dari hasil uji kubus $150 \mathrm{~mm}$ atau dari silinder dengan diameter $150 \mathrm{~mm}$ dan tinggi 300 $\mathrm{mm}(\mathrm{MPa})$

Fc :Kekuatan tarik dari hasil uji belah silinder beton (MPa)
F'cr :Kekuatan tekan beton rata-rata yang dibutuhkan, sebagai dasar pemilihan perancangan campuran beton (MPa)

$\mathrm{S} \quad$ :Deviasi Standar (s) (MPa)

Kekuatan beton yang dibuat tersebut disesuaikan dengan kebutuhan konstruksi bangunan bersumber pada besarnya beban yang wajib ditopang dan ukuran struktur beton selaku komponen sesuatu bangunan.

Bahan tambahan ataupun admixture merupakan bahan- bahan yang ditambahkan kedalam kombinasi beton pada saat ataupun sepanjang pencampuran itu berlangsung dimana peranan dari bahan tambahan ini digunakan buat memenuhi kesesuaian beton pada pekerjaan tertentu dalam hal mengganti sifat- sifat, menghemat biaya, waktu yang efektif serta lain- lain.

Tipe bahan tambahan untuk beton dikelompokan dalam 5 kelompok ialah: accelerating, air- entraining, water reducer, and set- controling, finely devided mineral serta miscellaneous (American Civil Institute Committee, 1986).

Secara garis besar bahan tambah yang digunakan beton bisa dibedakan jadi 2 ialah bahan tambah yang bersifat kimiawi (chemical admixture) serta bahan tambah yang bersifat mineral( additive).

1. Bahan tambah kimia

Jenis bahan tambah dibedakan menjadi tujuh tipe bahan tambah (American Standard Testing and Material, 1995):

a. Tipe A yaitu jenis beton yang dibuat dengan pengurangan air di dalam campurannya

b. Tipe B yaitu jenis beton yang dibuat sedemikian rupa sehingga waktu pengerasannya diperlambat.

c. Tipe $\mathrm{C}$ yaitu jenis beton yang dibuat sedemikian rupa 
sehingga waktu pengerasannya dipercepat.

d. Tipe D yaitu gabungan antara penggunaan air yang sedikit dan pengerasan beton yang lebih lambat.

e. Tipe E yaitu gabungan antara penggunaan air yang sedikit dan pengerasan beton yang lebih cepat.

f. Tipe $F$ yaitu gabungan antara penggunaan air yang sedikit dan level pengerasan beton yang lebih cepat.

g. Tipe $\mathrm{G}$ yaitu gabungan antara penggunaan air yang sedikit dan level pengerasan beton yang lebih lambat.

2. Bahan tambah mineral (additive)

Bahan tambah mineral ini merupakan bahan tambah yang dimaksudkan untuk memperbaiki kinerja beton. Bahan tambah mineral ini cenderung bersifat penyemenan. Beberapa bahan tambah mineral ini adalah pozzolan, fly ash, slag, dan silica fume.

Bahan tambah yang direncanakan pada sesuatu kombinasi beton didetetapkan penggunaannya bersumber pada desain sifat beton yang diinginkan dan ketersediaannya dalam pembuatan beton. Saat ini pertumbuhan teknologi yang menopang hajad hidup manusia terus maju serta tumbuh.

Ada berbagai tipe bangunan konstruksi yang didesain serta dibagun buat fungsi tertentu. Tiap- tiap bangunan tersebut dibentuk dengan tipe beton yang bermacam- macam.

Sebagai contoh tipe bangunan infrastruktur semacam jembatan, jalan layang maupun bangunan yang dilalui lalu lintas padat. Beton yang digunakan merupakan desain beton yang mempunyai kemampuan pengerasan yang cepat. Tujuannya supaya bangunan tersebut bisa lekas difungsikan dalam waktu singkat.

Khusus bangunan yang dibangunan dengan jarak yang lumayan jauh dari tempat pembuatan beton masal ataupun mixing plan umumnya memakai desain beton tipe pengerasan yang diperlambat.

\section{BAHAN DAN METODE}

Jenis penelitian yang dilakukan berupa pembuatan campuran beton berdasarkan SNI dengan memberikan bahan tambah yang terbuat dari limbah ampas tebu.

Penelitian awal dilakukan dengan melakukan uji komponen pada semua bahan yang digunakan untuk membuat beton K-300 yang direncanakan.

Limbah ampas tebu diolah dengan cara dilakukan pembakaran ampas tebu hingga diperoleh abu berupa serbuk halus berwarna hitam pekat. Selanjutnya dengan konsentrasi yang telah dikonsepkan diawal. Abu tersebut di tambahkan ke dalam adukan beton yang dibuat dengan variasi konsentrasi yang ditentukan sebelunya.

Penelitian dilakukan di PT. Cinta Manis yang menghasilkan ampas tebu sebagai bahan baku yang diolah menjadi additive beton. Sedangkan pembuatan beton, uji bahan dan kuat tekan beton dilaksanakan di laboratorium Fakultas Teknik Universitas PGRI Palembang.

Adapun yang menjadi target penelitian ini untuk menghasilkan bahan additive beton yang terbuat dari bahan alami berupa limbah pabrik yang berasal dari hasil perkebunan lokal yang ada di wilayah Sumatera Selatan,

Uji komponen bahan dilakukan dalam beberapa hari dengan tahapan sebagai berikut:

1) Pemeriksaan Agregat Halus dan Kasar

2) Pemeriksaan Kadar Air

3) Pemeriksaan Kadar Lumpur 
4) Pemeriksaan Berat Isi Gembur dan Padat Agregat Halus

5) Pemeriksaan Berat Jenis dan Penyerapan Air Agregat Halus

6) Pemeriksaan Analisa Ayakan Agregat Halus

Jumlah Sampel yang dibutuhkan adalah sebagai berikut

1. Variasi waktu : 3 buah (hari)

2. Variasi campuran abu ampas tebu: 4 buah $(0 \%, 5 \%, 10 \%$, dan 20\%)

3. Banyaknya sampel : 3 buah per masing-masing sampel

Jadi jumlah sampel yang dibutuhkan adalah: 3 × 4 × $3=36$ buah sampel.

Berdasarkan pada hasil uji komponen bahan baku untuk pembuatan sampel di labor didapatkan data sebagai berikut:

\section{Modulus kehalusan}

Bersumber pada hasil riset modulus kehalusan pasir tanjung raja mencapai 2,21-3, pasir tanjung raja dikatagorikan pasir kasar.

2. Kotoran organik

Bersumber pada hasil pengecekan kotoran organik pada pasir tanjung raja mencapai Nomor 5 yang diarahkan oleh standar warna organik.

3. Kandungan lumpur

Bersumber pada hasil pengecekan kandungan lumpur yang ada pada pasir tanjung raja cuma 0 , $51 \%$, sehinga pasir tanjung raja memenuhi standar bangunan, sebab isi kandungan lumpur yang diizinkan dalam pembangunan merupakan 5 , $0 \%$.

Hasil pemeriksaan di labor tentang komponen agregat kasar BP 3/4" diperoleh data sebagai berikut :

1. Modulus kehalusan

Berdasarkan hasil penelitian modulus kehalusan Agregat kasar mencapai $7,03 \%$.
2. Berat Isi Lepas sebesar $1,276 \%$

3. Berat Isi Padat sebesar 1,389\%

4. Berat Jenis; semu (2,67\%), Dasar Kering (2,54\%), Dasar Jenuh Kering Permukaan $(2,59 \%)$

5. Penyerapan mencapai $1,90 \%$.

Berdasarkan hasil pemeriksaan Agregat Kasar BP 1/2" di labor dapat diuraikan sebagai berikut :

1. Modulus kehalusan

Berdasarkan hasil penelitian modulus kehalusan Agregat kasar mencapai $7,68 \%$.

2. Berat Isi Lepas sebesar $1,325 \%$

3. Berat Isi Padat sebesar 1,398\%

4. Berat Jenis; semu (2,68\%), Dasar Kering (2,56\%), Dasar Jenuh Kering Permukaan $(2,60 \%)$

5. Penyerapan mencapai $1,74 \%$.

Pada perencanaan kombinasi ini digunakan abu ampas tebusebagai bahan tambah. Ada pula jumlah dari abu ampas tebuyang digunakan didalam perencanaan kombinasi ini ialah $0 \%, 5 \%, 10 \%$, serta $20 \%$ dari jumlah berat semen. Benda uji yang dibuat ialah berupa kubus dengan dimensi $15 \mathrm{~cm} \times 15 \mathrm{~cm} \times 15 \mathrm{~cm}$, yang dibuat sebanyak 36 buah ialah untuk umur beton 7 hari, 14 hari serta 28 hari dimana pada tiap umurnya dibuat 3 sampel. Hasil dari beton yang memakai abu limbah ampas tebu ini bakal jadi perbandingan dengan beton normal yang dibuat.

Perawatan ini dicoba untuk memperoleh kekuatan tekan beton yang besar ialah dengan metode merendam beton segar dalam air hingga dengan umur yang dikehendaki supaya kekuatan tekan bisa tercapai sesuai rencana pada usia tersebut. Perlu dicermati bahwasanya perawatan ini dicoba sehabis beton membeku supaya proses hidrasi tidak begitu cepat yang bakal menyebabkan keretakan pada beton sebab kehabisan air yang begitu cepat. 
Pengujian uji kuat tekan dicoba sehabis melewati masa perendaman sepanjang 28 hari. Ada pula langkahlangkah kerja dari pengujian kuat tekan beton merupakan sebagai berikut:

1) Benda uji yang sudah dirawat serta sudah lumayan umur buat pengujian kuat tekan beton diambil dari tempat perawatannya.

2) Keringkan benda uji tersebut dengan memakai lap kemudian dicoba pengukutran ukuran serta volume.

3) Timbang benda uji.

4) Taruh benda uji tersebut kedalam mesin penekan. Sehabis itu tekan benda uji tersebut. Besar beban akan tertera pada skala yang terdapat pada mesin kuat tekan.

Hasil uji kuat tekan beton yang dibuat di Laboratorium Beton Universitas PGRI Palembang di Rekap serta di analisis dengan rumusan kuat tekan beton. Hitung kuat tekannya dengan memakai rumus sebagai berikut:

$$
\sigma=\frac{P}{A} \mathrm{~kg} / \mathrm{cm}^{2}
$$

keterangan:

$\sigma:$ Kuat Tekan $\left(\mathrm{kg} / \mathrm{cm}^{2}\right)$

P: Beban Maksimum ( $\mathrm{N}$ atau $\mathrm{Kg}$ )

A: Luas penampang Benda Uji

$\left(\mathrm{mm}^{2}\right.$ atau $\left.\mathrm{cm}^{2}\right)$.

\section{HASIL DAN PEMBAHASAN}

Tabel 1. Hasil Pengujian Beton Normal

\begin{tabular}{|c|c|c|c|c|}
\hline No. & $\begin{array}{c}\sigma \mathrm{b}_{\mathrm{i}} \\
28 \mathrm{hari} \\
\left(\mathrm{kg} / \mathrm{cm}^{2}\right)\end{array}$ & $\begin{array}{c}\left(\sigma \mathrm{b}_{\mathrm{i}-}\right. \\
\sigma \mathrm{bm}) \\
\left(\mathrm{kg} / \mathrm{cm}^{2}\right)\end{array}$ & $\begin{array}{c}\left(\sigma \mathrm{b}_{\mathrm{i}-}\right. \\
\sigma \mathrm{bm})^{2}\end{array}$ & $\begin{array}{c}\text { Perhitungan } \\
=353,86 \mathrm{~kg} / \mathrm{cm}^{2}\end{array}$ \\
\cline { 3 - 4 } & 359.59 & 5,74 & 32,91 & $\begin{array}{c}{ }^{2}=\frac{\sqrt{\left(\sigma b i-\sigma b m^{2}\right)}}{n-1} \\
=5,46 \mathrm{~kg} / \mathrm{cm}^{2}\end{array}$ \\
\hline 2 & 348.72 & 5,13 & 26,35 & $\begin{array}{c} \\
\sigma \mathrm{bk}=\sigma \mathrm{bm}-(1,64 \times 5) \\
=344,9 \mathrm{~kg} / \mathrm{cm}^{2}\end{array}$ \\
\hline 3 & 353.25 & 0,60 & 0,36 & \\
\hline Total & 1061,57 & Total & 59,62 & \\
\hline
\end{tabular}

Berdasarkan hasil uji labor kuat tekan beton dengan formula beton normal tanpa additive di dapatkan bahwasannya kuat tekan beton berada dikisaran terendah di $348,72 \mathrm{~kg} / \mathrm{cm}^{2}$. Sedangkan nilai tertinggi berada di angka 359,59 $\mathrm{kg} / \mathrm{cm}^{2}$. Setelah dilakukan pengolahan data didapat bahwa kuat tekan karakteristik beton sebesar $344,9 \mathrm{~kg} / \mathrm{cm}^{2}$.

Table 2. Beton dengan Penambahan Abu Ampas Tebu 5\%

\begin{tabular}{|c|c|c|c|c|}
\hline \multirow[b]{2}{*}{ No. } & $\sigma_{\mathrm{bi}}$ & & $(\sigma \mathrm{bi}-\bar{\sigma} \mathrm{bm}) 2$ & \multirow{5}{*}{ 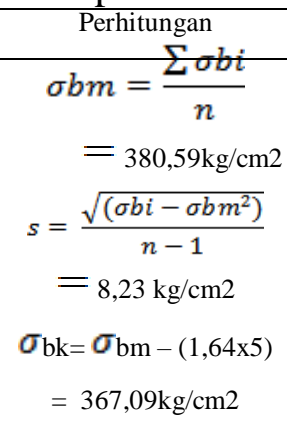 } \\
\hline & $\begin{array}{c}28 \text { hari } \\
(\mathrm{kg} / \mathrm{cm} 2)\end{array}$ & $\begin{array}{c}\left.\sigma_{\mathrm{bm}}\right) \\
(\mathrm{kg} / \mathrm{cm} 2)\end{array}$ & & \\
\hline 1 & 383.90 & 3,31 & 10,95 & \\
\hline 2 & 371.22 & 9,37 & 87,83 & \\
\hline 3 & 386.66 & $-6,06$ & 36,76 & \\
\hline Total & 1141,78 & Total & 135,54 & \\
\hline
\end{tabular}


Berdasarkan hasil uji labor kuat tekan beton dengan variasi beton additive $5 \%$ di dapatkan bahwa kuat tekan beton berada dikisaran terendah di 371,22 $\mathrm{kg} / \mathrm{cm}^{2}$. Sedangkang nilai tertinggi berada di angka 386,66 kg/ $\mathrm{cm}^{2}$. Setelah dilakukan pengolahan data didapat bahwa kuat tekan karakteriastik beton sebesar
$367,09 \mathrm{~kg} / \mathrm{cm}^{2}$. Hasil uji labor ini menunjukan terjadinya kenaikan kuat tekan beton sebanyak 6,43\% dari kondisi desain beton normal yang dibuat tanpa additive. Hal ini menunjukkan bahwa penambahan bahan additive berpengaruh positif terhadap kualitas beton yang dibuat.

Tabel 3. Beton dengan Penambahan Abu Ampas Tebu $10 \%$

\begin{tabular}{|c|c|c|c|c|}
\hline \multirow[b]{2}{*}{ No. } & \multirow{2}{*}{$\begin{array}{c}\sigma \mathrm{b}_{\mathrm{i}} 28 \text { hari } \\
\left(\mathrm{kg} / \mathrm{cm}^{2}\right)\end{array}$} & \multirow{2}{*}{$\begin{array}{c}\left(\sigma \mathrm{b}_{\mathrm{i}-}\right. \\
\sigma \mathrm{bm}) \\
\left(\mathrm{kg} / \mathrm{cm}^{2}\right)\end{array}$} & \multirow{2}{*}{$\begin{array}{c}\left(\sigma \mathrm{b}_{\mathrm{i}-}\right. \\
\sigma \mathrm{bm})^{2}\end{array}$} & \multirow{5}{*}{ 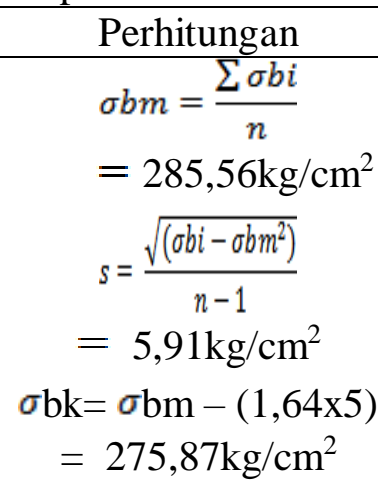 } \\
\hline & & & & \\
\hline 1 & 291.75 & 6,19 & 38,31 & \\
\hline 2 & 279.97 & 5,59 & 31,20 & \\
\hline 3 & 284.96 & 0,60 & 0,36 & \\
\hline Total & 856,68 & Total & 69,87 & \\
\hline
\end{tabular}

Berdasarkan hasil uji labor kuat tekan beton dengan kandungan beton additive $10 \%$ diperoleh bahwa kuat tekan beton berada dikisaran terendah di $279,75 \mathrm{~kg} / \mathrm{cm}^{2}$. Sedangkang nilai tertinggi berada di angka $291,75 \mathrm{~kg} / \mathrm{cm}^{2}$. Setelah dilakukan pengolahan hasil uji coba didapat bahwa kuat tekan karakteristik beton sebesar 275,87 $\mathrm{kg} / \mathrm{cm}^{2}$. Nilai kuat tekan mengalami penurunan sebesar 20,01\% dari kualitas beton normal. Berarti penambahan abu ampas tebu sebanyak $10 \%$ justru mengakibatkan penurunan kualitas beton yang dibuat.

Tabel 4. Beton dengan Penambahan Abu Ampas Tebu $20 \%$

\begin{tabular}{|c|c|c|c|c|}
\hline \multirow[b]{2}{*}{ No. } & $\sigma \mathrm{b}_{\mathrm{i}}$ & & $\left(\sigma \mathrm{b}_{\mathrm{i}-}\right.$ & \multirow{5}{*}{ 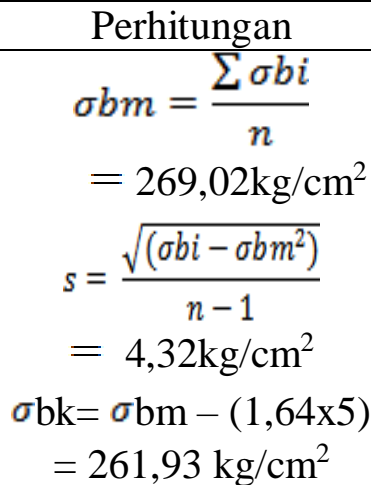 } \\
\hline & $\begin{array}{c}28 \text { hari } \\
\left(\mathrm{kg} / \mathrm{cm}^{2}\right)\end{array}$ & $\begin{array}{c}\sigma \mathrm{bm}) \\
\left(\mathrm{kg} / \mathrm{cm}^{2}\right)\end{array}$ & $\sigma \mathrm{bm})^{2}$ & \\
\hline 1 & 273.54 & 4,53 & 20,51 & \\
\hline 2 & 264.94 & 4,08 & 16,61 & \\
\hline 3 & 268.56 & 0,45 & 0,21 & \\
\hline Total & 807,05 & Total & 37,33 & \\
\hline
\end{tabular}


Berdasarkan hasil uji labor kuat tekan beton dengan komposisi beton additive $20 \%$ di dapatkan bahwa kuat tekan beton berada dikisaran terendah di $264,94 \mathrm{~kg} / \mathrm{cm}^{2}$. Sedangkang nilai tertinggi berada di angka $273,54 \mathrm{~kg} / \mathrm{cm}^{2}$.
Setelah dilakukan pengolahan data didapat bahwa kuat tekan karakteristik beton sebesar 261,93 $\mathrm{kg} / \mathrm{cm}^{2}$. Penambahan abu ampas tebu menunjukkan penurunan kualitas beton secara konsisten sebesar 24,05\%

Tabel 5. Hasil Uji Kuat Tekan Beton Karakteristik

\begin{tabular}{|c|c|c|}
\hline \multirow[t]{2}{*}{ Kondisi Beton } & $\begin{array}{l}\text { Umur Beton } \\
\text { (Hari) }\end{array}$ & \multirow[t]{2}{*}{$\sigma \mathrm{bk}$} \\
\hline & 28 Hari & \\
\hline Karakteristik (K) Beton Normal & 344,9 & $\mathrm{Kg} / \mathrm{cm}^{2}$ \\
\hline $\begin{array}{l}\text { Karakteristik (K) Beton dengan } \\
\text { Penambahan Abu Ampas Tebu 5\% }\end{array}$ & 367,09 & $\mathrm{Kg} / \mathrm{cm}^{2}$ \\
\hline $\begin{array}{l}\text { Karakteristik (K) Beton dengan } \\
\text { Penambahan Abu Ampas Tebu } 10 \%\end{array}$ & 275,87 & $\mathrm{Kg} / \mathrm{cm}^{2}$ \\
\hline $\begin{array}{l}\text { Karakteristik (K) Beton dengan } \\
\text { Penambahan Abu Ampas Tebu 20\% }\end{array}$ & 261,93 & $\mathrm{Kg} / \mathrm{cm}^{2}$ \\
\hline
\end{tabular}

Hasil dari uji labor yang dilaksanakan didapatkan hasil bahwa penambahan Abu Ampas Tebu (AAT) sebanyak $5 \%$ dapat menambah kuat tekan beton tersebut 6,43\% lebih tinggi dari kuat tekan beton normalnya.

Namun penambahan AAT yang lebih besar dari $5 \%$ terhadap semen dalam beton tersebut justru menurunkan kualitas kuat tekan betonnya. Hal ini berarti jumlah kadar $5 \%$ AAT dapat dimanfaatkan untuk peningkatan kuat tekan beton.

Hasil tersebut menunjukkan persentase AAT dengan optimasi $5 \%$ sama seperti yang dilakukan di Universitas Sam Ratulangi dan Universitas Muhammadiah Malang. Namun berbeda dengan yang dilakukan di UNAN optimal additive adalah $15 \%$.

Analisa dari hasil penelitian tersebut menunjukkan bahwa ampas tebu yang berasal dari lokasi yang berbeda menghasilkan AAT yang bervariasi.

\section{KESIMPULAN}

Penambahan Additive berupa Abu Ampas Tebu (AAT) mempengaruhi kualitas beton berupa kuat tekan beton. Penambahan AAT yang optimal adalah $5 \%$ dari berat semen yang mampu menambah kuat tekan beton mencapai lebih dari 6,43 dari beton normal. Menambah additive AAT lebih dari $5 \%$ jelas berpengaruh pada penurunan kuat tekan beton. Pada beton mutu tinggi K-300 masih bisa ditingkatkan mutu kuat tekannya dengan penambahan Abu Ampas Tebu dengan konsentrasi tertentu. Ampas Tebu sebagai limbah dari produksi gula dimanfaatkan sebagai bahan additive alami pada beton dengan konsentrasi tertentu

\section{DAFTAR PUSTAKA}

American Civil Institute Committee. (1986). State-of-the-Art Report on AlkaliAggregate Reactivity. 212. IR- 81, from

http://civilwares.free.fr/ACI/MCP04/ 2211r 98.pdf

American Standard Testing and Material. (1995). Standard Specification for Chemical Admixtures for Concrete. C.494. 1995: 254, from 
https://id.scribd.com/document/3399 29492/ASTM-C494-pdf-pdf

Karimah, R., \& Wahyudi, Y. (2016). Pemakaian Abu Ampas Tebu Dengan Variasi Suhu Sebagai Substitusi Parsial Semen Dalam Campuran Beton, Media Teknik Sipil. Volume 13. Nomor 2. 167-173. Jurusan Teknik Sipil - Fakultas Teknik Univ. Muhammadiyah Malang. http://ejournal.umm.ac.id/index.php/j mts/article/view/2563

https://doi.org/10.22219/jmts.v13i2.2 $\underline{563}$

Mulyadi, S., Dahlan, D., Adril, E. (2012) Pengaruh Persen Massa Hasil Pembakaran Serbuk Kayu Dan Ampas Tebu Pada Mortar Terhadap Sifat Mekanik Dan Sifat Fisisnya, Jurnal Ilmu Fisika (Jif), Volume 4. Nomor 1. 31-39, Laboratorium Material dan Struktur, Jurusan Fisika, FMIPA UNAND http://jif.fmipa.unand.ac.id/index.php /jif/article/view/71

https://doi.org/10.25077/jif.4.1.31$\underline{39.2012}$

Mulyono, Tri. (2003). Teknologi Beton. Yogyakarta: Penerbit Andy.

Murdock, L., J., \& Brook, K., M.(1999). Bahan Dan Praktek Beton. Jakarta: Penerbit Erlangga.

Rompas, G.,P., Pangouw, J.,D., Pandaleke, R., \& Mangare, J.B. (2013). Pengaruh Pemanfaatan Abu Ampas Tebu Sebagai Substitusi Parsial Semen Dalam Campuran Beton Ditinjau Terhadap Kuat Tarik Lentur Dan Modulus Elastisitas, Jurnal Sipil Statik Vol.1 No.2. 82-89. Fakultas Teknik Jurusan Teknik Sipil Universitas Sam Ratulangi https://ejournal.unsrat.ac.id/index.ph $\mathrm{p} / \mathrm{jss} /$ article/view/926

Sagel, R., Kole, P., \& Kusuma, G., .H. (1977). Pedoman Pengerjaan Beton. Jakarta: Penerbit Erlangga.

Sumardi, K. (1998). Teknologi Beton dan Bahan Beton. Bandung: Politeknik Negeri Bandung

Surat Keputusan Standar Nasional Indonesia. (1990). Tata Cara Perhitungan Struktur Beton Untuk Bangunan Gedung. T-15-1990-03, from https://docfoc.com/sksni-t-15-199103-tata-cara-perhitungan-strukturbeton-untuk-bangunan-gedung

Surdia, T., \& Saito, S. (1992). Pengetahuan Bahan Teknik. Jakarta: Penerbit PT. Pradnya Paramita.

Wangsadinata, W. (1989). Pedoman Beton. Jakarta: Departemen Pekerjaan Umum. 693.5 WAN p c.1, from http://perpustakaan.pupukkaltim.com lopac/index.php?p=show_detail\&id= 4902\&keywords= 